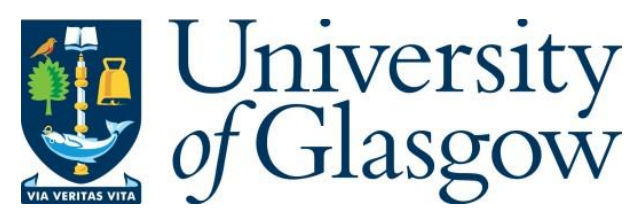

Aliyev, H. (2019) Why are some civil wars more lethal than others? The effect of pro-regime proxies on conflict lethality. Political Studies,

(doi: $10.1177 / 0032321719862752$ )

There may be differences between this version and the published version. You are advised to consult the publisher's version if you wish to cite from it.

http://eprints.gla.ac.uk/189312/

Deposited on: 1 July 2019

Enlighten - Research publications by members of the University of Glasgow http://eprints.gla.ac.uk 


\title{
Why are some civil wars more lethal than others? The effect of pro-regime proxies on conflict lethality
}

\author{
Huseyn Aliyev \\ University of Glasgow
}

Accepted for publication in Political Studies

\begin{abstract}
Previous large- $N$ studies on conflict lethality have focused in large part either on structural factors, or on the properties of key conflict protagonists - governments and rebels. This article challenges the dyadic two-actor approach to studying conflict lethality that examines exclusively the key actors of the dyad, and - on the example of pro-regime militias - hypothesizes that participation of extra-state actors in civil wars can exert significant influence on battlefield lethality. It is proposed here that pro-regime militias can swell the number of combat deaths through, first of all, acting as "extra boots" on the ground, providing governments with auxiliary forces, local intelligence and enabling incumbents to launch more effective and often more deadly attacks on insurgents. Militias also affect the number of battle deaths by forcing rebels to protect their civilian support bases, which exposes insurgents to lethal government attacks. This assumption is empirically tested on 88 civil wars from 1981 to 2015 with militia presence. The findings show that the presence of pro-regime militias in civil wars is highly conducive to the incidence of highcasualty conflicts.
\end{abstract}

\section{Introduction}

Which factors account for combat lethality ${ }^{1}$ in civil wars? Amidst the general decline in numbers of battlefield deaths in interstate armed conflicts since the end of World War II (Lacina et al., 2006), it has been established that civil wars cause over $90 \%$ of conflict-related deaths in contemporary armed conflicts (Lacina, 2006: 276). Existing research on civil war lethality has largely prioritised structural causes of conflict lethality, such as ethnic

${ }^{1}$ I estimate civil war lethality by the number of combat deaths sustained by armed actors on both sides of the dyad. Lethality of civil war is defined in this study in terms of the increase of battle deaths beyond the threshold of 999 deaths in a given calendar year, which in the Uppsala Conflict Data Program (UCDP) terms distinguishes a "low-intensity" conflict from a "major civil war" (Harbom and Wallensteen, 2005: 634). Estimating conflict lethality in battle deaths has been described in previous studies as "a reasonable measure of the scale of combat" (Lacina, 2006: 278). 
mobilisation (King, 2001; Sambanis, 2001; Eck, 2009), political regime type (Lacina, 2006; Downes, 2008), conflict dynamics (Fearon, 2004; Kalyvas, 2006: 2890), conflict type (Balcells and Kalyvas, 2014), geography and topography (Buhaug et al., 2009), and economic factors (Collier et al., 2004; Regan and Norton, 2005; Lacina, 2006). The role of agency in the lethality of conflict-associated violence has thus far been limited to the dyadic dimension, emphasising either state capacity (Lyall and Wilson, 2009), or rebel strength (Buhaug, 2006; Wood, 2014; Cunningham et al., 2009). Notwithstanding existing studies, research on conflict lethality still lacks systematic analysis on the role of agency (Eck, 2009: 369). Not much is known as to whether the presence or absence of certain conflict protagonists explains the lethality of violence. Most types of non-state actors including, but not limited to, criminal organisations, private military contractors, warlords, militias, and other armed non-state protagonists - irrespective of their contribution to violence - have been traditionally excluded from the two-sided analysis of intrastate conflicts. ${ }^{2}$

Of all other armed extra-state actors, pro-regime militias (PRMs) ${ }^{3}$ are identified, along with governments and rebels, as prominent stakeholders in post-World War II armed conflicts (Carey et al., 2013). A study by Carey, Mitchell, and Lowe (2013) has shown that pro-regime militias were involved in over $80 \%$ of all intrastate conflicts since 1981. A burgeoning empirical literature portrays militias as important powerbrokers in most intrastate conflicts of the Cold War period (Campbell and Brenner, 2002; Mazzei, 2009; Ahram, 2011; Aliyev, 2017; 2018). Carey et al. (2013) found that the presence of pro-regime militias accounts for higher incidence of civil war. A growing body of literature examined the role of militias in civilian victimisation and genocidal violence (Cohen and Nordås, 2015; Stanton, 2015; Koren, 2017). It is well documented that PRMs are used as tools of repression against civilians (Mitchell et al., 2014) and political rivals of ruling regimes (Aliyev, 2016). Notwithstanding the key role of militias in perpetrating atrocities, little is known as to whether the presence of PRMs increases the rates of conflict-related violence. A hypothesis raised by Kalyvas (2006: 108) that militias "may also cause an escalation in violence" has

${ }^{2}$ For example, in his study on multi-actor model of intrastate conflicts, Cunningham (2006) identified only three generally defined types of conflict protagonists: government; domestic rebels and external actors.

${ }^{3}$ The term "pro-regime militias" refers to non-state actors organised into armed groups operating outside of regular security forces, but either formally or informally associated with the government. This definition echoes Bohmelt and Clayton's (2016: 1) understanding of pro-regime militias as groups with "a link to the executive" and "some level of organization" that differ from paramilitary groups, which are trained and created by governments to serve as part of regular armed forces. 
never been either tested empirically or developed further theoretically. The impact of militias on conflict lethality remains a missing variable in research on lethality of violence.

This article argues that the deployment of militias has a potential to increase the level of conflict-related violence accounting for higher number of battlefield deaths and contributing towards the transformation of low-intensity conflict into a major civil war. Bearing in mind that the research on militias' involvement in civil wars is currently in its infancy, exploring the PRMs' role in intrastate conflicts allows to improve our understanding of more general functions performed by quasi-state actors in armed conflicts. This study is one the few large$\mathrm{N}$ contributions to explore the role of extra-state actors outside of the government-rebels dichotomy in the context of civil war lethality. Through its focus on extra-dyadic actors in civil wars, this study contributes to broader research on armed conflict which is of relevance for the wider community of scholars working on Politics and International Relations.

This article proceeds further by examining the key strands of existing research on civil war lethality. It then introduces theoretical argument on pro-regime militias' association with battlefield deaths and discusses mechanisms through which militias are expected to affect conflict lethality. After the presentation of the argument, this article proceeds with discussing the data and research design. This section is followed by empirical discussion and presentation of findings. The article concludes by summarising findings and contributions, as well as discussing prospects for further research on the topic of extra-dyadic actors and conflict lethality.

\section{Explaining conflict lethality}

Research on explanations of conflict lethality has emphasised the primary significance of the type of conflict and ethnic factors. Although a number of other factors were mentioned, such as regime type (Downes, 2008), economic development (Lacina et al., 2006) and geography (Buhaug et al., 2009), there is no consensus in the literature as to whether these variables account for conflict lethality. By contrast, Balcells and Kalyvas (2014) have found a positive relationship between conflict lethality and three key types of intrastate conflicts: irregular, conventional and symmetric nonconventional wars. The key finding with regard to the relationship between the type of civil war and conflict lethality was that conventional conflicts "tend to be more severe in terms of battlefield lethality" (Balcells and Kalyvas, 
2014: 1390). Instead, "irregular conflicts generate greater civilian victimisation" (2014: 1390).

Another cause of conflict lethality - ethnicity - had been explored in depth by Eck (2009). The key finding of Eck's (2009: 369) research was that "ethnically mobilized armed conflicts have a 92 percent higher risk for intensification to war." It was theorised that ethnic fragmentation enables easier recruitment into rebel groups and ensures loyalty and commitment of rebel fighters (Weinstein, 2007; Aliyev, 2019b; Aliyev and Souleimanov, 2019). This allows ethnicity-based rebel groups to escalate violence far more effectively than insurgent organisations that recruit their members along non-ethnic lines. A few other scholars have tested the relationship between ethnic fractionalisation and conflict lethality, but their findings conflict Eck's results. For example, Lacina (2006: 287) has found negative correlation between ethnic polarisation and conflict lethality. In addition, Balcells and Kalyvas (2014: 1405) discovered that "ethnic fractionalization reduces battlefield severity." However, unlike Eck (2009), no other scholars conducted an in-depth nuanced inquiry into the relationship between ethnic conflicts and the lethality of violence. This shows that the role of ethnicity in conflict lethality is still a contested variable.

More commonly, conflict lethality regularly emerges as one of control variables in various studies that neither focus specifically on the phenomenon, nor seek to theoretically explain its dynamics and characteristics (Rouhana et al., 1994; Collier et al., 2004; Harbom and Wallensteen, 2005; Heger and Salehyan, 2007; Esteban and Ray, 2008; Krain, 2014; Hultman and Peksen, 2015; Petersohn, 2017). As the above described strands of research on conflict lethality have dominated the discipline, there are few if any explanations emphasising the role of extra-dyadic actors. Previous research has systematically tended to disregard the impact of extra-state (or quasi-state) actors - apart from anti-regime groups - on the lethality of conflict violence. Even with the steady transition from the dyadic two-actor perception of intrastate conflicts towards multi-actor models (Cunningham et al., 2009; Gleditsch, 2007), previous large-N analyses on the lethality of civil wars largely ignored the role of extra-state conflict stakeholders, focusing instead on the key dyadic actors: governments and rebels (Pruitt and Kim, 2005; Wucherpfennig et al., 2012). How do proregime actors contribute towards conflict lethality? More specifically, which part do proregime militias play in these processes?

\section{Pro-regime proxies and civil war lethality}


The expectation that pro-regime militias contribute towards conflict lethality is premised on the inherent assumption that the presence of extra-dyadic actors in intrastate conflicts affects dynamics of civil wars and influences their outcomes (Cunningham, 2006; Gleditsch, 2007). Previous studies on multi-actor civil wars have found that larger numbers of armed actors involved in a conflict are likely to contribute to higher conflict lethality (Cunningham, 2011; Cunningham, 2013). For example, in-fighting amongst various rebel factions was found to be highly conducive to conflict lethality (Bakke et al., 2012; Gade et al., 2019; Maoz and SanAkca, 2012). Multi-actor conflicts were also described as significantly harder to resolve through negotiated settlements (Cunningham, 2006; Svensson, 2007).

Following the logic that presence of multiple rebel groups in a conflict is likely to increase group fragmentation and in-fighting (Bakke et al., 2012), I expect that participation of pro-regime proxies in civil wars is likely to complicate conflict dynamics and to increase potential for lethal violence. I identify two mechanisms through which militias are expected to increase battlefield lethality in intrastate conflicts. Firstly, PRMs act as "force multipliers" increasing the number of pro-regime forces and therefore enhancing possibilities for higher conflict lethality. Secondly, pro-regime militias produce "collateral lethality" by attacking rebel civilian support bases and forcing insurgents to defend their civilian constituencies, which potentially exposes the rebels to violent confrontations with pro-regime forces and intensifies lethal violence.

\section{“Force-multipliers"}

Following the argument that multi-actor conflicts are harder to resolve due to the diversity of interests involved (Cunningham, 2006), which eventually leads to higher levels of battlefield lethality (Lacina, 2006), it might be assumed that an introduction of an extra actor - proregime militias - adds another layer towards the complexity of multi-actor civil wars. On the one hand, militias are "extra boots" on the ground increasing the number of government forces and assisting the incumbent with counterinsurgency (Lyall, 2010). Militias' knowledge of terrain, rebel constituencies and tactics is an asset for governments (Souleimanov and Aliyev, 2015b), which enables the government forces to target insurgents more effectively, and often more lethally (Staniland, 2015). This access to intelligence both facilitates selective targeting and leads to increasing the incumbent's capacity to locate and physically eliminate rebels. In many cases, both selective targeting of rebel leaders and lethal attacks on rebel 
bases are combined owing to the local intelligence provided by PRMs, as was the case with Colombian government's campaign against FARC rebels in Colombia (Mazzei, 2009), and with Janjaweed militias in Sudan (Stanton, 2015). As demonstrated by Kalyvas (2006: 17476), access to intelligence is a key towards enabling conflict actors to choose between selective and indiscriminate violence. For example, local intelligence supplied by pro-regime Sons of Iraq militias during the Sunni Awakening allowed the US coalition to target insurgents selectively (which caused few casualties), along with conducting air strikes on alQaeda camps killing dozens of militants (Long, 2008).

On the other hand, it is well documented that PRMs are often employed to do "dirty jobs" for governments, such as extra-judicial executions (Stanton, 2015), human rights violations (Mitchell et al., 2014), mass killings (Koren, 2017), and sexual violence (Cohen and Nordås, 2015), directed not only against civilian sympathisers of rebels, but also against suspected insurgents. In Kalyvas's (2006: 108) words, militias" "reputation for atrocity is well established." Militias' propensity for violence should be expected to contribute towards conflict lethality by potentially increasing opportunities for confrontations with rebel. For instance, it has been reported that house-to-house searches for ISIS members by the Popular Mobilization Front (PMF) Shiite militias in Sunni areas of Iraq have frequently resulted in deadly skirmishes not only with insurgents hiding amongst civilians, but also with disgruntled villagers resisting militias' incursions (Shaheen, 2015; Ismaeel, 2017)

The PRMs' contribution toward conflict lethality becomes more obvious when they are deployed in direct combat roles in counterinsurgency (COIN) campaigns. As militias engage rebels in open confrontations, they are likely to both suffer casualties and to inflict losses on rebels. Unlike rebel losses, militia casualties are seldom reported or included in official statistics (Peic, 2014: 167). However, it is uncommon for incumbents to use militias as the main COIN force; rather they are deployed as auxiliary units to support the army (Bohmelt and Clayton, 2016: 198). More typically, PRM attacks on insurgents are accompanied, or followed by army offensives. During Sudan's long-lasting war against rebels in Darfur and South Sudan, Janjaweed attacks on rebel-controlled areas were usually accompanied or preceded by air strikes or artillery barrages conducted by the army (Stanton, 2015: 915). A similar pattern had been observed in Colombia, Peru, former Yugoslavia, Syria, and other civil conflicts involving PRMs. For example, extensive aerial bombardment almost always preceded pro-Russian Chechen militias' advance on insurgent positions (Lyall, 2010; Souleimanov et al., 2018). The military strategy of relying on air strikes and heavy artillery, followed by land offensives by auxiliary forces enables incumbents to reduce causalities 
amongst regular forces and to effectively weaken rebel defences prior to sending its troops. Although the tactic limits government casualties, it is conducive to high rebel and militia combat deaths. It has also been described that incumbents tend to send militias to directly confront rebels in densely populated areas, such as urban settlements, where the risk of casualties is particularly high and the chances for the governments troops to avoid lethal contact with the rebels are low (Mazzei, 2009; Lilja and Hultman, 2011).

Along with the PRMs' advantages of an offensive force, militias are also well-known for their defensive functions. Defined by Clayton and Thomson (2014) as civilian defence forces (CDFs), such militia formations are also known as village guards, citizens' patrols or residents' protection units. In contrast to such PRMs as Colombia's AUC (Autodefensas), Sudanese Janjaweed, Rwandan Interahamwe or Serb Arkan's Tigers - all of which were tasked with raiding and military offensives - the Turkish anti-PKK village guards, Peru's Rondas Campesinas, Iraqi Sons of Iraq and the Philippines' Manticao Village Defence Force were used almost exclusively to protect populated areas from rebel attacks and to collect intelligence amongst the local population. Clayton and Thomson (2014: 922-23) described defensive militias' functions as centred on identifying insurgents, increasing local support and civilians' participation. The existence of CDFs offers significant advantages to the incumbent by enabling governments to control rebel-threatened areas without positioning military outposts in each rural settlement. Although the PRMs' capacities to hold these settlements in cases of large-scale rebel advances are limited (Forney, 2015), they nonetheless are capable of repelling smaller rebel attacks and inflicting casualties on insurgents before the arrival of reinforcements (Gurcan, 2015). Besides, the presence of CDFs within areas of rebel operation and influence allows incumbents greater access to intelligence and therefore increases their ability to harass and target insurgents. The use of militias as guards, village patrols and security units invites rebel attacks mostly because such objects are seen as soft targets. Unlike police- and army-protected facilities, areas defended by PRMs may appear easier to capture. For instance, it is reported that Kurdish PKK preferred targeting villages and settlements protected by the Village Guards militias instead of attacking areas defended by the Turkish security forces, because the rebels knew that rather than fighting militias would often surrender or flee (Aydin and Emrence, 2015: 68). In contrast to regular forces, PRMs are also poorly trained and organised. In most cases CDFs are also more lightly armed than regular forces (Forney, 2015), which makes them an easy target for rebels. Governments' unwillingness to provide advanced weapons and equipment to PRMs is often due to concerns of militia members switching sides, selling their weapons to 
rebels or criminals, or due to potential negative consequences for the regime in cases where militias are involved in mass civilian persecution (Downes, 2008). By targeting CDFs, rebels not only cause casualties on militias and suffer their own battle deaths, but they also invite retaliatory attacks by better armed and equipped government forces who can interpret the loss of militia-controlled territories as the lack of territorial control. Capturing militia-controlled villages and towns may prove to be an easy task for insurgents. However, it also means that rebels could become easy targets of government counteroffensives or air strikes. For example, the Taliban has found it easy to repeatedly drive off lightly-armed pro-government militias in Logar province (Taylor, 2013), but it has proven prohibitively costly for the insurgents to maintain control over the villages after expelling the government proxies as the Taliban combatants became exposed to full-scale government offensives. Reusing militia defence facilities in Logar, such as the former German military base, has proven similarly costly for the insurgents, because these installations were exposed to coalition air strikes. Therefore, deploying militias in Logar enabled the government to weaken local Taliban inflicting high casualty toll on the insurgents. The presentation of militias as soft targets, or as a decoy for the rebels, often works as part of COIN strategy in forcing rebels out of their hideouts and physically eliminating them, while they seek to protect the newly acquired territories.

Unlike rebels, militias rarely control territory on their own, instead establishing their bases and training camps in government-held areas. Often, militias share their bases with formal security forces. This means that rebels are usually deprived of opportunity to target militias without engaging the army. For example, attempts by Chechen militants to confront pro-government kadyrovtsy militias - who were seen by rebels as easier target than heavilyarmed Russian troops - have routinely resulted in militias calling for air strikes on rebels (Lyall, 2010; Souleimanov and Aliyev, 2016). After engaging in skirmishes with kadyrovtsy, insurgents were eventually surrounded by the superior Russian forces as the militias' strategy was to prevent rebel attackers from withdrawing quickly following an attack (Souleimanov, 2007). Therefore, rebels' efforts to target militias are likely to cause combat deaths to both sides regardless of the actual balance of power between the rebels and militias.

Related to the above point is the fact that militias are often seen by governments as expendable forces which, as debated by the "principal-agent" paradigm (Mitchell et al., 2014; Ahram, 2016), can be delegated tasks that the regime is unwilling to deal with, either due to human rights implications or owing to possibly high death toll for regular armed forces. Hence, the prospect of high casualties amongst militias often emerges as of least concern for 
the government. Either deployed as auxiliary forces or as CDFs, militias are expected to cripple the insurgency at all costs, including physically eliminating rebel forces by exposing them to government forces.

\section{Collateral lethality}

Previous studies emphasised that attacking civilians is a viable strategy of conflict escalation that has been systematically employed by both governments and insurgents (Hultman, 2007; Wood, 2014). However, civilian victimisation, or one-sided violence, is not always synonymous with battle field lethality and civil wars with high numbers of civilian casualties may have relatively few battle deaths. This means that the increased level of conflictassociated violence - a significant part of which is often directed against the civilian population - that might be associated with militia presence in civil wars does not necessarily result in the growth of battle-related deaths amongst the government and rebel forces. Thus, distinguishing between one-sided violence against civilians in armed conflicts and battlerelated violence amongst belligerents is critical to understanding civil war lethality. This study is primarily concerned with conflict lethality framed by battlefield losses amongst combatants (Lacina, 2006; Balcells and Kalyvas, 2014). This form of conflict lethality is not only widely used as a measure of conflict incidence (Fearon, 2004; Hultman, 2007), but is also employed as a valid indicator of the lethality of violence (Lacina, 2006). The role of proregime militias in civilian targeting has been examined by previous studies (Ahram, 2014; Cohen and Nordås, 2015). By contrast, militia presence as a factor conducive to higher numbers of battlefield deaths through their use of one-sided violence against civilians remains unexplored.

In the context of civil wars, militias are frequently mobilised by incumbents to assist them in weakening rebels either through direct combat roles, or by functioning as village guards, intelligence-gathering networks, self-defence units, vigilante groups, or as death squads selectively assassinating anti-regime individuals. ${ }^{4}$ A significant part of these activities is directed against the civilian population rather than enemy combatants. However, even in

4 Although the use of militias enables incumbents to practice selective targeting, which has been described to result in decreased violence (Kalyvas, 2006; Lyall, 2010), the same militia groups might also be deployed in the same conflict to commit acts of indiscriminate violence. For example, Colombia's AUC paramilitaries were known to both conduct selective assassinations and to commit mass killings. Hence, it is hard to associate PRM involvement with the reduction of indiscriminate retributive violence. 
their non-combat functions, militias contribute towards higher levels of battlefield lethality. The PRMs efforts of eroding rebels' civilian support structures may put insurgent groups under the excessive pressure to protect their civilian bases by increasing patrolling of civilian spaces and more defensive deployments to civilian areas, which would logically expose rebel forces to higher levels of confrontation with pro-regime forces.

Scholars have argued that the success of a rebellion hinges on rebels' ability to maintain and protect their civilian support base (Weinstein, 2007; Mampilly, 2012; Arjona et al., 2015). Support from the local population provides insurgents with supplies, shelter, funding and intelligence, alongside with recruits and ideological sympathisers (McColl, 1969). Insurgencies with weak civilian support base are often described as doomed to fail (Kilcullen, 2005). Owing to close relationship between rebels and the local population, it is imperative for the rebels to ensure that their civilian sympathisers are protected and that the local population prefers collaboration over denunciation (Kalyvas, 2006: 177). To maintain such a relationship with civilians, a "carrots and sticks" strategy is commonly used by rebels to both entice the locals into supporting insurgents and to thwart their collaboration with the incumbent.

In case if PRMs succeed in eroding popular support for rebels by brutally cracking down on rebel sympathisers, as was the case during Russia's COIN in Chechnya (Souleimanov, 2007; Souleimanov and Aliyev, 2015a), the rebels are forced to protect their support bases as the only feasible strategy of maintaining their legitimacy and preserving funding sources. For some rebel groups - particularly for the "sons of the soil" (Fearon and Laitin, 2011) organisations that derive their legitimacy from local support - the loss of civilian bases poses a direct existential threat. In that case, increasing protection of their civilian supporters and exposing their forces to confrontation may emerge as a viable survival strategy. All else being equal, rebels faced with increased persecution of their civilian support structures are left with few other options, but to retaliate by increasing the numbers and severity of their attacks on the incumbent. Since many PRMs operate either alongside regular armed forces, or in close coordination with them, often rebels are neither capable of, nor willing to distinguish between the formal security forces and militias. In consequence, increased militia activity indirectly translates into higher rebel activity, which inevitably translates into higher battle deaths for all dyadic actors.

The presence of CDFs amongst civilians does not only directly threaten rebel support bases, but is also indicative of anti-rebel sentiments amongst the population. In other words, the presence of militia informants amongst the locals signals to rebels that their own 
informants and sympathisers are in danger. In order to weed out pro-government sympathisers in their areas of operation and control, rebels can be compelled to increase their presence in civilian populated areas, which similarly to other scenarios will lead to increased confrontation with state security forces resulting in potential battle deaths on both sides. Thus, militia presence can exacerbate the battle for "hearts and minds," encouraging rebels to step up their activities.

Related to the above point is the argument, first raised by Stanton (2015: 901), that not all militias carry out violence against civilians and that pro-government proxies are more likely to engage in targeting civilians mostly when government choose to carry out attacks on civilians. However, even in cases when PRMs choose to avoid victimising the insurgents' civilian support bases, rebels can be expected to object militia presence amongst their constituencies and launch attacks against them, increasing battle deaths. The mere presence of PRMs amongst civilians signals to rebels weakening of their control and influence over civilians in the area, and is therefore potentially conducive to armed confrontations and lethality amongst the conflict actors.

It is noteworthy that increased government violence against rebel constituents might persuade rebels to change their tactics, including withdrawing and negotiating. However, negotiations or concessions become less favourable for rebels when they are facing militia violence. On the one hand, peaceful conflict settlement is rarely in the interests of militias, who might lose their funding from patrons and their income from illicit activities. Indeed, PRMs are generally described as "peace-spoilers" (Aliyev, 2019a). On the other hand, governments seldom invite militias to the negotiation table, instead choosing to distance themselves from PRMs, or to completely conceal their links with militias (Ahram, 2014). In consequence, government opponents receive limited guarantees of security from militia attacks during and after peace processes (Svensson, 2007; Johnston, 2007; Lanz, 2011; Souleimanov et al., 2018). For instance, the heavy presence of Interahamwe militias - the major perpetrators of the Rwandan genocide - amongst pro-government forces in 1994 Rwanda, reduced the possibility of negotiated settlement between the RPF rebels and the government (Stedman, 1997).

This argument has also a flip side. Once rebels found themselves under the mounting pressure from government forces - with militia activity further increasing the costs imposed on rebels - rebel groups are less capable to inflict greater casualties on the government. This does not mean that conflict is unlikely to cause high combatant lethality, or that as rebels become weaker conflict is likely to phase down. Rather, rebel weakness is likely to encourage 
the government to step up its activities in an effort to supress the insurgency. This would inflict higher casualties on rebels, multiplying the total number of battle deaths. ${ }^{5}$ For example, the decline of Free Syrian Army and other moderate Syrian rebel groups from 2013 to 2014 has led to increased government offensives (including active deployment of Shabiha militias) and growing rebel casualties. ${ }^{6}$ All of the above suggests that PRMs have numerous opportunities of contributing towards the lethality of armed conflicts.

The proposed hypothesis on pro-regime proxies' lethality does not argue that the presence of PRMs is the key factor pushing conflict from low to high lethality levels, rather it suggests that militias function as one of determinants contributing towards higher battlefield lethality in intrastate conflicts. The involvement of militias potentially contributes to conflict lethality through the "force multiplier" potential, or that an injection of more military resources by the incumbent that creates more opportunities for violence, and by increasing the costs imposed on rebels and by enabling incumbents to step up their persecution of dissent at a relatively low cost and with limited accountability. Thus:

Hypothesis: Civil conflicts that include PRMs are more likely to become more lethal than civil conflicts that do not.

\section{Data and variables}

The data on pro-regime militias is taken from the UCDP Non-State Conflict Dataset (NSCD) v.2.5-2015. ${ }^{7}$ The data set offers cross-sectional data on non-state armed groups active from 1946 to 2014. Since the NSCD does not distinguish between PRMs and other types of armed groups, the UCDP conflict database was consulted in order to identify armed groups involved in intrastate conflicts as either pro- and anti-government organisations. All pro-government groups on the NSCD were coded as PRMs. This has enabled me to identify 240 militia groups as engaged in 88 civil wars between 1981 and 2014. Only those militia organisations,

${ }^{5}$ This assumption might also apply to stronger rebels and weak governments, in which case rebels are likely to escalate their attacks and increase government casualties.

${ }^{6}$ According to Syrian Observatory for Human Rights (http://www.syriahr.com/en/), over 32,000 antigovernment rebels were killed in 2014 (18,800 in 2013). Pro-Assad forces lost over 25,000 casualties that year $(30,240$ in 2013).

${ }^{7}$ I choose to code my own pro-regime militia variable rather than relying on existing databases as the current PRM variable is best suited for the purposes of this study. 
which participated in civil wars, were included into the current data set. The data on civil wars comes from the Uppsala Conflict Data Program (UCDP)/Peace Research Institute Oslo (PRIO) Armed Conflict Dataset (ACD) v.4-2016, which contains information on all intrastate conflicts from 1946 to 2015. The UCDP's definition of intrastate armed conflict identifies civil war as an incompatibility over government or territory that results in a minimum of 25 battle-related deaths per calendar year and involves a government and one or more non-state parties (UCDP, 2008). The list of 88 intrastate conflicts with pro-regime militia involvement was composed on the basis of the ACD data $\operatorname{set}^{8}$ and the NSCD. The dataset is time-series cross-sectional with conflict episodes as cross-sectional component. Each recurring intrastate war is coded as a new conflict episode.

Conflict lethality measured in battle deaths is a main dependent variable of this study. The data on battle-related deaths in each civil war was borrowed from the UCDP BattleRelated Deaths Dataset v.5-2016, which contains the data on battlefield lethality from 1989 to 2015. The UCDP terminology, however, does not allow controlling for conflicts either failing to reach a 999 deaths threshold, but exceeding well beyond the 25 deaths minimum, or for civil war exceeding 999 battle-deaths per year. To account for variation in conflict lethality, I introduce additional thresholds (25-100; 100-1,000; 1,000-10,000; 10,000 plus), ${ }^{9}$ estimated as dummies in the robustness check (logit) models only. Lethality measures conflict-related violence in the UCDP's terms of battlefield lethality, excluding civilian casualties and other non-battle-related deaths occurring during the conflict. This limits the definition of conflict lethality strictly to military confrontations amongst the belligerents. ${ }^{10}$

The pro-regime militia presence (PRM presence) is a key explanatory variable of this study. The PRM presence is a binary variable that codes the PRM presence from each civil war's onset until its termination. Each year of civil war constitutes a single observation. The PRM presence is measured from the moment militia group was established, or from the conflict onset in case if militias were already present prior to the start of conflict, until the

\footnotetext{
${ }^{8}$ The UCDP indicates conflict participants involved in each conflict episodes, which has enabled identifying PRMs involved in each conflict.

${ }^{9}$ These thresholds are introduced in order to control not only for the UCDP's "low-intensity" (from 25 to 999 deaths) and "major civil war" (over 999 deaths), but also for conflicts with battle field lethality beyond these thresholds.

${ }^{10}$ Since no data is available specifically on militia fatalities and killings amongst combatants, I do not separate these deaths from all other battlefield casualties. Theoretically, all deaths undertaken by militias are part of battle-related casualties occurring during intrastate conflicts.
} 
year all PRMs involved in the conflict were demobilised or the conflict terminated, whichever comes first. In 49 civil wars, pro-regime militia were present before the start of conflict. In $80 \%$ of cases, the onset of conflict encouraged the emergence of additional militias. In over two-thirds of civil wars more than one militia organisation was involved throughout the conflict period. In $82 \%$ of civil conflicts with militia presence, PRMs continued to function until conflict termination, or, for ongoing conflicts, until the end of recorded period. ${ }^{11}$

To account for additional explanations of conflict lethality, a number of control variables commonly employed in research on conflict dynamics were added. To explain the role of ethnicity, this article introduces a categorical variable ethnic conflict, modelled on a similar variable from Fearon and Laitin (2004), which provides information as to whether a civil war is a non-ethnic conflict (0), ambiguous or mixed conflict (1) or a clearly defined ethnic conflict (2). As an additional measure of ethnicity's impact on civil war characteristics, a variable of ethnic fragmentation was borrowed from Wimmer et al. (2009) as a log of percentage of country's ethnic fragmentation. These two variables on ethnicity were introduced in order to control for whether the conflict type (ethnic or non-ethnic) interacts with the PRMs' effect on conflict lethality, as argued in previous studies on conflict severity and lethality (Eck, 2009; Stanton, 2015).

Whether a country is a democracy or not is included as a control variable because democracies are likely to keep battle-related deaths at a minimum. Regime type is a dummy that codes countries, in accordance with the Polity IV dataset, ${ }^{12}$ on a scale from 10 as full democracies to -10 as autocracies. To account for the effect of country size, a variable on population size was added as a log of population data from the World Bank database. To control for the role of economic development, a log of real Gross Domestic Product (GDP) per capita, measured in thousands of current US dollars was also adopted from the World Bank database. A variable on the percentage of mountainous terrain in each country was taken from Fearon and Laitin (2003) as a factor accounting for rebel capacity to hide and regroup and therefore possibly influence the conflict lethality. These variables were chosen as

${ }^{11}$ Since only in 15 conflicts PRMs were demobilised before the end of civil war, this study does not control for the relationship between militia demobilisation, or disappearance, and the decline in conflict lethality. One noteworthy caveat, however, is that it is not the demobilisation of PRMs, but their weakening or decline that might be expected to have an effect on conflict lethality and its termination.

${ }^{12}$ See http://www.systemicpeace.org/polity/polity4.htm. 
a standard set of controls commonly tested in large-N analyses on civil war (Fearon and Laitin, 2004; Cunningham, 2006).

\section{Empirical analysis}

This study hypothesised that civil wars with the presence of pro-regime militias are more likely to become more lethal for combatants. I use the UCDP battle-related deaths to run an OLS (ordinary linear regression) model on the log of all battle deaths. Table 1 presents the findings, which show that the PRM variable is highly significant and is in positive direction, pointing towards positive relationship between militia participation and conflict lethality.

$<$ Table 1>

Descriptive statistics render further support to the findings on the relationship between the PRM presence and conflict lethality. Only $32 \%$ of civil wars involving militias have failed to develop into conflicts with high levels of lethality. The majority of civil wars with PRM presence have either started as major high-lethality wars, or rapidly escalated into such conflicts. This further observation supports an assumption that it is likely that PRMs are a feature of intense civil conflicts. A time-series analysis of battlefield lethality in civil wars with at least one militia group present (see Figure 1), shows that numerous conflicts $(86 \%)$ produced between 500 to 20,000 battle deaths per year.

<Figure 1.>

In some civil wars where PRMs were deployed as soon as the conflict started - due to either immediate mobilisation or deployment of already functioning militias - it is hard to observe the precise effect of PRM presence on the increase of conflict lethality. In other conflicts, where militias were employed well after the conflict onset, the effect becomes more notable. For example, prior to the establishment of the United Self-Defence Forces of Colombia (AUC) in 1997, Colombian government's COIN against FARC and ELN guerrillas caused 10,731 battle deaths from 1964 to 1997. The emergence of AUC spiralled the lethality of violence: the battle toll from 1997 until the AUC's dissolution in 2008 reached 9,876 
deaths, increasing the average number of battle deaths per year from 320 (in pre-1997 period) to over 820. Similarly the deployment of Janjaweed militias by the Sudanese government against rebels in South Sudan increased the average battlefield lethality toll from around 1,380 to almost 2,000 battle deaths per year.

With regards to control variables, most notable finding is related to ethnic conflict, which is in negative direction, and is highly statistically significant. These results render support for Lacina's (2006), and Balcells and Kalyvas's (2014) findings on the lack of correlation between conflict lethality and ethnicity. It is noteworthy that the number of ethnic conflicts amongst civil wars fought with militia presence is significant. Under half of civil wars with militia participation can be explicitly identified as ethnic conflicts. Another $22 \%$ of cases fall into the category of mixed ethnic conflicts, where mobilisation occurred both along ethnic and ideological causes, such as Mexico's conflict with the EZLN, or Uganda's war with the LRA. Perhaps the most obvious explanation of these findings is that ethnic conflicts with militia presence account only for $20 \%$ of all battlefield deaths and mixed (ethnic/nonethnic) conflicts for a bit more than $30 \%$ of lethality. Given the relatively low lethality rates in ethnic civil wars, the PRM involvement may not directly affect their lethality. As determined by Lyall (2010: 14), in ethnic conflicts, PRMs tend to rely on selective violence, which can cause less both military and civilian casualties and often, but not always, contributes towards conflict de-intensifying. Lyall (2010: 1) notes that the deployment of ethnic militias in Chechen conflicts enabled Russian authorities to weaken the insurgency.

Other statistically significant result amongst the controls was produced by the regime type variable, which is in negative direction, suggesting that (more) democratic regimes are unlikely to experience major civil wars. Also, the roughness of terrain is both positive and significant. While previous studies arrived to diverse conclusions with regard to the association between the population and civil war lethality (Lacina, 2006; Eck, 2009), studies on conflict lethality has found that terrain had "no explanatory power" (Lacina, 2006: 286). Research on rebel strength similarly found the terrain roughness of little relevance (Buhaug et al., 2009; Fortna, 2012). Nonetheless the number of civil wars in the current dataset, which occurred in countries with the percentage of mountainous terrain exceeding $20 \%$ of total territory, is rather significant (over 30\%). In other cases, despite relatively low percentage of mountainous territory in relation to country size, COIN was conducted almost exclusively in mountainous areas. These cases include Chechnya (as part of Russia), COINs in Thailand, India (Kashmir), Indonesia (East Timor) and Sudan. This suggests that the results pertaining to the roughness of terrain should be taken more seriously in research on conflict lethality. 
The variable on ethnic fragmentation, although statistically insignificant, remains positive. Whereas ethnic conflict dummy controls for whether the conflict is ethnic or not, ethnic fragmentation variable is a log of ethnic divisions within the conflict-affected country. Since these two variables represent different aspects of ethnicity's role in conflicts, it could be expected that they produce contradictory outcomes. Hence, the positive relationship between ethnic fragmentation and the incidence of high casualty conflicts may not necessarily occur in ethnic conflicts. For example, the Philippines' long-lasting COIN against the CPP (Communist Party of Philippines) took place in a country with the high level of ethnic fragmentation, but was not an ethnic conflict. A similar case is Thailand's conflict with the CPT, as well as the Iraqi COIN campaigns against al-Qaeda and the Islamic State. Population size and economic development have coefficients below 0 and are not significant. A counter variable for conflict years remains positive, but insignificant, hinting that conflict duration is not necessarily conducive to or associated with higher conflict lethality.

\section{Expanding the analysis}

Additional models were designed to assess the robustness of the above findings. Another issue of concern is a possible endogeneity between conflict lethality and the involvement of PRMs. Provided that PRMs emerge during violent conflicts, how can one be sure that they further increase conflict lethality? However, relatively few militia organisations emerged in the midst of civil conflicts. In over half of conflicts (49 out of 88), militias were already present by the start of conflict in one form or the other, well before the increase of battle deaths. About two-thirds of civil wars started without a PRM present, but had militias assembled in the first or second year of fighting. Bearing in mind that only under $40 \%$ of conflicts developed into major civil wars during their first or second year - and amongst those the majority already had active PRMs - the argument that PRMs tend to emerge as a response to increasing conflict lethality finds limited support in the data. ${ }^{13}$

${ }^{13}$ Nonetheless there is a probability that conflict escalation encourages already existing PRMs to expand their numbers, acquire better weapons and to engage more actively in military operations. For example, following the escalation of Syrian conflict, pro-regime Shabiha militia was "re-created" and expanded from the previously existent (under the same name) groups of armed smugglers and racketeers loyal to the regime (see Amor and Sherlock, 2014). Sudan's Janjaweed has similarly evolved in the course of the conflict from a loose tribal militia association to a heavily armed militia force. 
In the final part of the analysis, I seek to estimate whether the UCDP's threshold between a low intensity conflict (25 to 999 deaths) and a major civil war (over 900 deaths) affects these findings. For that purpose, I introduce several logit models, which set following battle deaths thresholds: 25 to 100 deaths, 100 to 1000, 1000 to 10000 and 10000 plus. While logit models with a static DV are not a good fit for capturing temporal dimensions of conflict lethality, they nevertheless allow controlling for the relationship between militia presence and fluctuations in battlefield lethality. The results, reported in Table 2, demonstrate that PRM presence remains highly statistically significant across all four models. It is noteworthy that the PRM variable is negative in the model for low-lethality conflicts (25 to 100 deaths). Increase in battle-deaths appeared to be particularly notable in the PRM effect on average and high lethality conflicts (Models 3 and 4).

<Table 2.>

Coefficient plots for logit regressions (see Figure 2), lend further support to the above observation on the significance of average (100 to 1,000) and high (10,000 and more) lethality conflicts. Each increase in PRM presence in models 2 and 4 is followed by the increase of battlefield fatalities. In Model 3 for observations ranging between 1,000 and 10,000 deaths per year, PRM participation becomes important only in the middle of conflicts. By contrast, PRM involvement, as shown in Model 1, has negative effect on conflict lethality in low-lethality conflicts, where it seems to decrease levels of lethality.

<Figure 2.>

\section{Conclusion}

The goal of this study was to examine whether the presence of pro-regime militias in civil wars has an effect on the lethality of civil wars. By conducting a large-N analysis of militias' impact, or the lack thereof, on battlefield lethality, this study has aimed to contribute to the literature on quasi-state actors in civil wars and agent-centred causes of conflict lethality. The claim that not only governments and rebels are involved in fighting civil wars, and are accountable for conflict lethality, but also such extra-state actors as militias, remained 
neglected in the existing literature on civil war dynamics. This study proposed and tested a hypothesis on the militias' role in escalating combat deaths in civil wars. The results of statistical tests demonstrate a strong positive relationship between militia presence and conflict lethality. These results were tested using additional variable operationalisation to control for levels of battlefield lethality. The findings demonstrated that militia presence is conducive to high-casualty conflicts, causing from 500 to over 1,000 battlefield deaths per year. While a causal relationship between militia presence and conflict lethality might require further and more detailed research, this study has shown that the presence of PRMs indicates that conflicts will likely become more lethal. Significance of ethnic conflict suggests that a more nuanced analysis is required in order to determine the exact impact of militias on the incumbent's and rebels' capacity and willingness to escalate violence in ethnic civil wars.

These findings offer a number of implications for future research and practice. Firstly, this study emphasised that armed extra-state actors, beyond the dimension of rebel groups, have a potential to affect the course and dynamics of violence in civil wars. Often neglected in the literature on dyadic aspects of civil war onset and incidence, all extra-state actors are commonly generalised as anti-government elements challenging the state either in collaboration with rebel groups or alongside them. Secondly, the deployment of proxy forces by the incumbent may not only increase civilian victimisation, but also swell the numbers of battle deaths, because pro-regime militias - along with functioning as "extra boots" on the ground - both provoke rebel retaliation and, due to the PRMs access to local information, enable incumbents to mount more effective attacks on insurgents. Although the capacity of militias to undermine rebel support bases through brutal persecution of civilians is well known, the link between this function of PRMs and conflict lethality has thus far been missing. Even less mobile, poorly armed and trained PRMs, such as CDFs, still retain the function of provoking revenge attacks and supplying the incumbent with invaluable intelligence. Lastly, this study further increases our knowledge about the role of pro-regime militias in armed conflicts. Departing from the presentation of PRMs as agents of genocide and civilian targeting, or as "political rather than military institution" (Kalyvas, 2006: 107), this article is one of the few large- $\mathrm{N}$ contributions to examine militias as a military force that affects civil war dynamics through its physical presence in conflict zones. 


\section{References}

Ahram A (2011) Proxy warriors: the rise and fall of state-sponsored militias. Stanford, CA: Stanford University Press.

Ahram A (2014) The role of state-sponsored militias in genocide. Terrorism and political violence 26 (3): 488-503.

Ahram A (2016) Pro-government militias and the repertoires of illicit state violence. Studies in Conflict \& Terrorism 39 (3): 207-226.

Aliyev H (2016) Strong militias, weak states and armed violence: Towards a theory of 'stateparallel' paramilitaries. Security Dialogue 47 (6): 498-516.

Aliyev H (2017) Pro-regime militias and civil war duration. Terrorism \& Political Violence. Online first DOI: 10.1080/09546553.2017.1393415.

Aliyev H (2018) When and how militias disband? Global patterns of pro-government militia demobilisation in civil wars. Studies in Conflict and Terrorism 42 (8): 715-734.

Aliyev H (2019a) 'No peace, no war' proponents? How pro-regime militias affect civil war termination and outcomes. Cooperation and Conflict 54 (1): 64-82.

Aliyev H (2019b) The Logic of Ethnic Responsibility and Progovernment Mobilization in East Ukraine Conflict. Comparative Political Studies 52 (8): 1200-1231.

Aliyev H and Souleimanov EA (2019) Ethnicity and conflict severity: accounting for the effect of co-ethnic and non-ethnic militias on battlefield lethality. Third World Quarterly 40 (3): 471-487.

Amor S and Sherlock R (2014) How Bashar al-Assad created the feared shabiha militia: an insider speaks. Telegraph, March 2014.

Arjona A, Kasfir N and Mampilly Z (2015) Rebel governance in civil war. Cambridge: Cambridge University Press.

Aysegul A and Emrence C (2015) Zones of Rebellion: Kurdish Insurgents and the Turkish State. Ithaca, NY: Cornell University Press.

Bakke KM, Cunningham KG and Seymour LJM (2012) A plague of initials: Fragmentation, cohesion, and infighting in civil wars. Perspectives on Politics 10 (2): 265-283.

Balcells L and Kalyvas S (2014) Does warfare matter? Severity, duration, and outcomes of civil wars. Journal of Conflict Resolution 58 (8): 1390-1418. 
Beck N, Katz JN and Tucker R (1998) Taking time seriously: Time-series-cross-section analysis with a binary dependent variable. American Journal of Political Science 42 (4): 1260-1288.

Böhmelt T and Clayton G (2017) Auxiliary Force Structure: Paramilitary Forces and Progovernment Militias. Comparative Political Studies, Online first: DOI: 0010414017699204.

Box-Steffensmeier J and Jones BS (2004) Event History Modeling: A Guide for Social Scientists. Cambridge: CUP.

Buhaug H (2006) Relative capability and rebel objective in civil war. Journal of Peace Research 43 (6): 691-708.

Buhaug H, Gates S and Lujala P (2009) Geography, rebel capability, and the duration of civil conflict. Journal of Conflict Resolution 53 (4): 544-569.

Campbell BB and Brenner AD (2002) Death squads in global perspective: Murder with deniability. Basingstoke: Palgrave Macmillan.

Carey SC, Mitchell NJ and Lowe W (2013) States, the security sector, and the monopoly of violence: A new database on pro-government militias. Journal of Peace Research 50 (2): 249-258.

Clayton G and Thomson A (2014) The Enemy of My Enemy is My Friend... The Dynamics of Self-Defence Forces in Irregular War: The Case of the Sons of Iraq. Studies in Conflict \& Terrorism 37 (11): 920-935.

Clayton G (2013) Relative rebel strength and the onset and outcome of civil war mediation. Journal of Peace Research 50 (5): 609-622.

Cohen DK and Nordås R (2015) Do States Delegate Shameful Violence to Militias? Patterns of Sexual Violence in Recent Armed Conflicts. Journal of Conflict Resolution 59 (5): 877-898.

Collier P, Hoeffler A and Soderbom M (2004) On the Duration of Civil War. Journal of Peace Research 41 (3): 253-73.

Collier P, Hoeffler A and Soderbom M (2008) Post-Conflict Risks. Journal of Peace Research 45 (4): 461-478.

Cunningham DE (2006) Veto players and civil war duration. American Journal of Political Science 50 (4): 875-892.

Cunningham DE, Gleditsch KS and Salehyan I (2009) It Takes Two. Journal of Conflict Resolution 53 (4): 570-597. 
Cunningham DE (2011) Barriers to peace in civil war. Cambridge: Cambridge University Press.

Cunningham KG (2013) Actor fragmentation and civil war bargaining: How internal divisions generate civil conflict. American Journal of Political Science 57 (3): 659672.

Downes A (2008) Targeting Civilians in War. Ithaca, NY: Cornell University Press.

Eck K (2009) From Armed Conflict to War: Ethnic Mobilization and Conflict Intensification. International Studies Quarterly 53 (2): 369-388.

Esteban J and Ray D (2008) Polarization, fractionalization and conflict. Journal of peace Research 45 (2): 163-182.

Fearon JD (2004) Why do some civil wars last so much longer than others?. Journal of Peace Research 41 (3): 275-301.

Fearon JD and Laitin DD (2003) Ethnicity, insurgency, and civil war. American political science review 97 (01): 75-90.

Fearon JD and Laitin DD (2011) Sons of the soil, migrants, and civil war. World Development 39 (2): 199-211.

Forney JF (2015) Who Can We Trust with a Gun? Information Networks and Adverse Selection in Militia Recruitment. Journal of Conflict Resolution 59 (5): 824-849.

Fortna VP (2012) Do Terrorists Win? Rebels' Use of Terrorism and Civil War Outcomes. International Organization 69 (3): 519-56.

Gade EK, Hafez MM and Gabbay M (2019) Fratricide in rebel movements: A network analysis of Syrian militant infighting. Journal of Peace Research Online first: 0022343318806940.

Gleditsch SK (2007) Transnational dimensions of civil war. Journal of Peace Research 44 (3): 293-309.

Gossman P (2000) “India's Secret Armies.” In Bruce B. Campbell and Arthur D. Brenner (eds.), Death Squads in Global Perspective: Murder with Deniability, 261-86. New York, NY: St. Martin's Press.

Gurcan M (2015) Arming civilians as a counterterror strategy: The case of the village guard system in Turkey. Dynamics of Asymmetric Conflict 8 (1): 1-22.

Harbom L and Wallensteen P (2005) Armed conflict and its international dimensions, 19462004. Journal of Peace Research 42 (5): 623-635.

Heger L and Salehyan I (2007) Ruthless Rulers: Coalition Size and the Intensity of Civil Conflict. International Studies Quarterly 51 (2): 385-403. 
Hultman L (2007) Battle losses and rebel violence: Raising the costs for fighting. Terrorism and Political Violence 19 (2): 205-222.

Hultman L and Peksen D (2017) Successful or Counterproductive Coercion? The Effect of International Sanctions on Conflict Intensity. Journal of Conflict Resolution 61 (6): 1315-1339.

Ismaeel B (2017) Reliance on militia forces sows more sectarian violence. Kurdistan24, February 10, accessible at: https://www.kurdistan24.net/en/news/0a3bf584-e3b84a58-86a2-722100e7672c/Reliance-on-militia-forces-sows-more-sectarian-cracks-inIraq.

Jentzsch C, Kalyvas S and Schubiger LI (2015) Militias in Civil Wars. Journal of Conflict Resolution 59 (5): 755-769.

Johnston P (2007) Negotiated settlements and government strategy in civil war: Evidence from Darfur. Civil Wars 9 (4): 359-377.

Kalyvas S (2003) The Ontology of "Political Violence:" Action and Identity in Civil Wars. Perspectives on Politics 1 (3): 475-94.

Kalyvas S (2006) The Logic of Violence in Civil War. Cambridge: Cambridge University Press.

Kilcullen DJ (2005) Countering global insurgency. Journal of Strategic Studies 28 (4): 597617.

King C (2001) The Myth of Ethnic Warfare: Understanding Conflict in the Post-Cold War World. Foreign Affairs 80 (6): 165-170.

Koren O (2017) Means to an end: Pro-government militias as a predictive indicator of strategic mass killing. Conflict Management and Peace Science 34 (5): 461-484.

Krain MR (2014) The Effects of Diplomatic Sanctions and Engagement on the Severity of Ongoing Genocides or Politicides. Journal of Genocide Research 16 (1): 25-53.

Kramer AE (2014) With borscht and rifle scopes, volunteers power Ukraine's forces. The New York Times, November 22.

Lacina B, Gleditsch NP and Russett B (2006) The declining risk of death in battle. International Studies Quarterly 50 (3): 673-680.

Lacina B (2006) Explaining the severity of civil wars. Journal of Conflict Resolution 50 (2): 276-289.

Lanz D (2011) Who gets a seat at the table? A framework for understanding the dynamics of inclusion and exclusion in peace negotiations. International Negotiation 16 (2): 275 295. 
Lilja J and Hultman L (2011) Intraethnic Dominance and Control: Violence Against CoEthnics in the Early Sri Lankan Civil War. Security Studies 20 (2): 171-197.

Long A (2008) The Anbar Awakening. Survival 50 (2): 67-94.

Lyall J and Wilson I (2009) Rage against the machines: Explaining outcomes in counterinsurgency wars. International Organization 63 (1): 67-106.

Lyall J (2010) Are coethnics more effective counterinsurgents? Evidence from the second Chechen war. American Political Science Review 104 (1): 1-20.

Mampilly ZC (2012) Rebel rulers: Insurgent governance and civilian life during war. Ithaca, NY: Cornell University Press.

Maoz Z and San-Akca B (2012) Rivalry and state support of non-state armed groups (NAGs), 1946-2001." International Studies Quarterly 56 (4): 720-734.

Mazzei J (2009) Death squads or self-defense forces: How paramilitary groups emerge and challenge democracy in Latin America. Chapel Hill, NC: University of North Carolina Press.

McColl RW (1969) The insurgent state: Territorial bases of revolution. Annals of the association of American geographers 59 (4): 613-631.

McCullagh P (1980) Regression models for ordinal data. Journal of the royal statistical society. Series B (Methodological): 109-142.

Mitchell NJ, Carey SC and Butler CK (2014) The Impact of Pro-Government Militias on Human Rights Violations. International Interactions 40 (5): 812-836.

Peic G (2014) Civilian defense forces, state capacity, and government victory in counterinsurgency wars. Studies in Conflict \& Terrorism 37 (2): 162-184.

Petersohn U (2017) Private military and security companies (PMSCs), military effectiveness, and conflict severity in weak states, 1990-2007. Journal of conflict resolution 61 (5): 1046-1072.

Pruitt DG and Kim SH (2004) Social Conflict: Escalation, Stalemate, and Settlement, $3^{\text {rd }}$ edition. Boston, MA: McGraw Hill.

Regan PM and Norton D (2005) Greed, Grievance, and Mobilization in Civil Wars. Journal of Conflict Resolution 49 (3): 319-336.

Rouhana NN and Fiske ST (1995) Perception of power, threat, and conflict intensity in asymmetric intergroup conflict: Arab and Jewish citizens of Israel. Journal of Conflict Resolution 39 (1): 49-81.

Salehyan I, Gleditsch KS and Cunningham DE (2011) Explaining external support for insurgent groups. International Organization 65 (4): 709-744. 
Salehyan I (2010) The Delegation of War to Rebel Organizations. Journal of Conflict Resolution 54 (3): 493-515.

Sambanis N (2001) Do Ethnic and Nonethnic Civil Wars Have the Same Causes? Journal of Conflict Resolution 45 (3): 259-282.

Shaheen K (2015) Iraqi militias have destroyed villages and displaced thousands, NGO says. The Guardian. March 18, accessible at:

https://www.theguardian.com/world/2015/mar/18/iraqi-army-has-destroyed-villagesand-displaced-thousands-ngo-says.

Souleimanov E (2007) Endless war: the Russian-Chechen conflict in perspective. Bern: Peter Lang.

Souleimanov E and Aliyev H (2015a) Individual Disengagement of Avengers, Nationalists and Jihadists: Why Ex-Militants Choose to Abandon Violence in the North Caucasus. Basingstoke: Palgrave Macmillan.

Souleimanov E and Aliyev H (2015b) Blood Revenge and Violent Mobilization: Evidence from the Chechen Wars. International Security 40 (2): 158-180.

Souleimanov E and Aliyev H (2016) Evaluating the Efficacy of Indigenous Forces in Counterinsurgency: Lessons from Chechnya and Dagestan. Small Wars \& Insurgencies 27 (3): 392-416.

Souleimanov E, Aliyev H and Ratelle J-F (2018) Defected and loyal? A case-study of antidefection mechanisms in Chechen paramilitaries. Terrorism \& Political Violence 30 (4): 616-636.

Staniland P (2015) Militias, Ideology, and the State. Journal of Conflict Resolution 59 (5): 770-793.

Stanton JA (2015) Regulating Militias Governments, Militias, and Civilian Targeting in Civil War. Journal of Conflict Resolution 59 (5): 899-923.

Stedman SJ (1997) Spoiler problems in peace processes. International security 22 (2): 5-53.

Svensson I (2007) Fighting with faith. Journal of Conflict Resolution 51 (6): 930-949.

Sundberg R, Eck K and Kreutz J (2012) Introducing the UCDP Non-State Conflict Dataset. Journal of Peace Research 49 (2):351-362.

Taylor A (2013) Afghanistan, February 2013: Anti-Taliban militias. The Atlantic. March 6, accessible at: https://www.theatlantic.com/photo/2013/03/afghanistan-february-2013anti-taliban-militias/100468/.

UCDP (2008) Definitions. Uppsala Conflict Data Project. Available at http://www.pcr.uu.se/research/UCDP. 
Vick K (2002) In Kurdish Turkey, a New Enemy. Village Guards, Empowered during War, Turn Guns on Returnees. Washington Post, October 31.

Weinstein J (2007) Inside Rebellion: The Politics of Insurgent Violence. Cambridge: Cambridge University Press.

Wimmer A, Cederman L-E and Min B (2009) Ethnic politics and armed conflict: A configurational analysis of a new global data set. American Sociological Review 74 (2): $316-337$.

Wood RM (2014) Opportunities to kill or incentives for restraint? Rebel capabilities, the origins of support, and civilian victimization in civil war. Conflict Management and Peace Science 31 (5): 461-480.

Wucherpfennig J, Metternich NW, Cederman L-E and Gleditsch KS (2012) Ethnicity, the state, and the duration of civil war. World Politics 64 (01): 79-115. 
Table 1. OLS (ordinary least squares) regression of battle-deaths

\section{Civil war lethality}

\begin{tabular}{|c|c|}
\hline PRMs & $\begin{array}{l}191.9 * * * \\
(418.66)\end{array}$ \\
\hline Ethnic conflict & $\begin{array}{l}-117.1 * * * \\
(255.424)\end{array}$ \\
\hline Ethnic fragmentation & $\begin{array}{l}183.9 \\
(908.966)\end{array}$ \\
\hline Regime type & $\begin{array}{l}-165.3 * * * \\
(36.430)\end{array}$ \\
\hline Real GDP per capita & $\begin{array}{l}-119.0 \\
(165.513)\end{array}$ \\
\hline Population size & $\begin{array}{l}-0.128 \\
(0.339)\end{array}$ \\
\hline Mountainous terrain & $\begin{array}{l}26.34 * * \\
(9.040)\end{array}$ \\
\hline Conflict duration & $\begin{array}{l}164.1 \\
(103.135)\end{array}$ \\
\hline Spline $1^{14}$ & $\begin{array}{l}387.6^{*} \\
(154.656)\end{array}$ \\
\hline Spline 2 & $\begin{array}{l}128.4^{*} \\
(568.438)\end{array}$ \\
\hline Spline 3 & $\begin{array}{l}-146.0 \\
(969.041)\end{array}$ \\
\hline Spline 4 & $\begin{array}{l}906.9 \\
(104.82)\end{array}$ \\
\hline Cons. & $\begin{array}{l}311.6^{*} \\
(142.609)\end{array}$ \\
\hline Number of observations & 958 \\
\hline R-Squared & 0.998 \\
\hline
\end{tabular}

Coefficients are reported. Standard errors (clustered by conflict year) are in parentheses.

$* \mathrm{p}<0.05, * * \mathrm{p}<0.01, * * * \mathrm{p}<0.001$

${ }^{14}$ A counter for conflict years was added in order to control for temporal aspects of conflict lethality and four cubic splines were estimated for serial correlation (Beck, Katz and Tucker, 1998). Each spline is designed to control for a 5-year period. 
Figure 1. Time-series analysis of battlefield lethality in civil wars

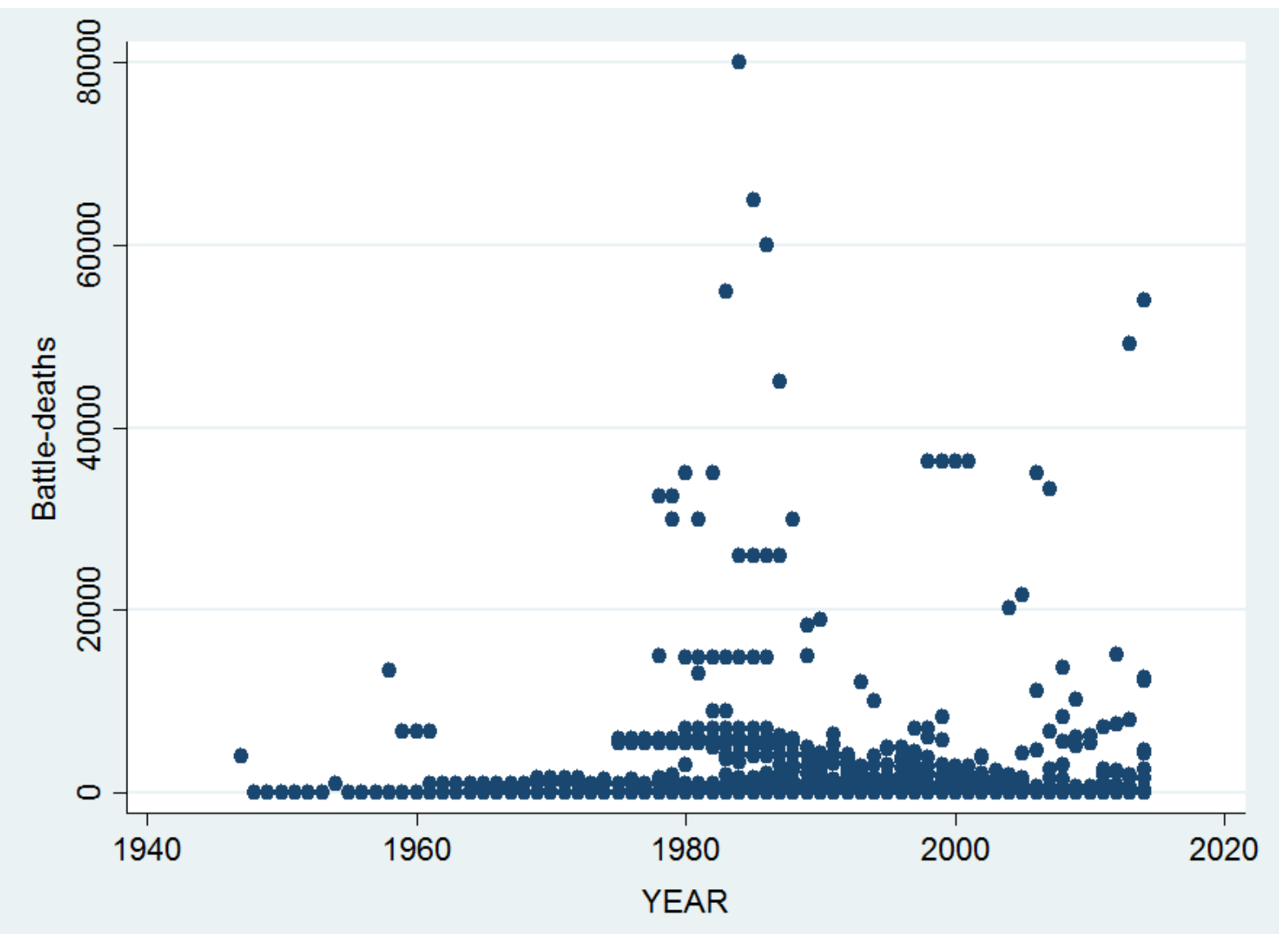


Table 2. Logit regression of battle-deaths thresholds

\begin{tabular}{|c|c|c|c|c|}
\hline & 25 to 100 & $\begin{array}{l}100 \text { to } \\
1,000\end{array}$ & $\begin{array}{l}1,000 \text { to } \\
10,000\end{array}$ & $10,000+$ \\
\hline PRMs & $\begin{array}{l}-1.516 * * * \\
(0.206)\end{array}$ & $\begin{array}{l}0.334 * \\
(0.154)\end{array}$ & $\begin{array}{l}0.894 * * * \\
(0.211)\end{array}$ & $\begin{array}{l}0.785^{*} \\
(0.328)\end{array}$ \\
\hline Ethnic conflict & $\begin{array}{l}-0.768 \\
(0.102)\end{array}$ & $\begin{array}{l}0.372 * * * \\
(0.980)\end{array}$ & $\begin{array}{l}0.620 \\
(0.092)\end{array}$ & $\begin{array}{l}-0.835 * * * \\
(0.235)\end{array}$ \\
\hline Ethnic fragmentation & $\begin{array}{l}-1.125^{* *} \\
(0.404)\end{array}$ & $\begin{array}{l}-0.420 \\
(0.328)\end{array}$ & $\begin{array}{l}0.872 * \\
(0.326)\end{array}$ & $\begin{array}{l}0.787 \\
(0.732)\end{array}$ \\
\hline Regime type & $\begin{array}{l}-0.212 \\
(0.014)\end{array}$ & $\begin{array}{l}-0.826^{* * * *} \\
(0.138)\end{array}$ & $\begin{array}{l}0.844 \\
(0.134)\end{array}$ & $\begin{array}{l}-0.822^{*} \\
(0.321)\end{array}$ \\
\hline Real GDP per capita & $\begin{array}{l}-0.634 \\
(0.062)\end{array}$ & $\begin{array}{l}0.148^{*} \\
(0.684)\end{array}$ & $\begin{array}{l}-0.251 \\
(0.575)\end{array}$ & $\begin{array}{l}-0.169 \\
(0.101)\end{array}$ \\
\hline Population size & $\begin{array}{l}5.420 \\
(3.100)\end{array}$ & $\begin{array}{l}-0.162 \\
(0.326)\end{array}$ & $\begin{array}{l}-1.960 \\
(1.970)\end{array}$ & $\begin{array}{l}-0.159 \\
(0.102)\end{array}$ \\
\hline Mountainous terrain & $\begin{array}{l}-0.149 * * * \\
(0.043)\end{array}$ & $\begin{array}{l}-0.973 \\
(0.335)\end{array}$ & $\begin{array}{l}0.417 \\
(0.031)\end{array}$ & $\begin{array}{l}0.605 \\
(0.637)\end{array}$ \\
\hline Conflict duration & $\begin{array}{l}0.270 * * \\
(0.084)\end{array}$ & $\begin{array}{l}-0.689 \\
(0.868)\end{array}$ & $\begin{array}{l}-0.265^{* *} \\
(0.090)\end{array}$ & $\begin{array}{l}-0.725 * * \\
(0.262)\end{array}$ \\
\hline Cons. & $\begin{array}{l}0.629 \\
(0.514)\end{array}$ & $\begin{array}{l}-2.590 * * * \\
(0.568)\end{array}$ & $\begin{array}{l}-1.639 * * \\
(0.515)\end{array}$ & $\begin{array}{l}-1.271 \\
(0.877)\end{array}$ \\
\hline Number of observations & 958 & 958 & 958 & 958 \\
\hline $\begin{array}{l}\text { Pseudo R2 } \\
\text { Log likelihood }\end{array}$ & $\begin{array}{l}0.125 \\
-440.881\end{array}$ & $\begin{array}{l}0.575 \\
-524.108\end{array}$ & $\begin{array}{l}0.377 \\
-535.118\end{array}$ & $\begin{array}{l}0.127 \\
-153.047\end{array}$ \\
\hline
\end{tabular}


Figure 3. Predictive margins (95\% CI's) of logit coefficients

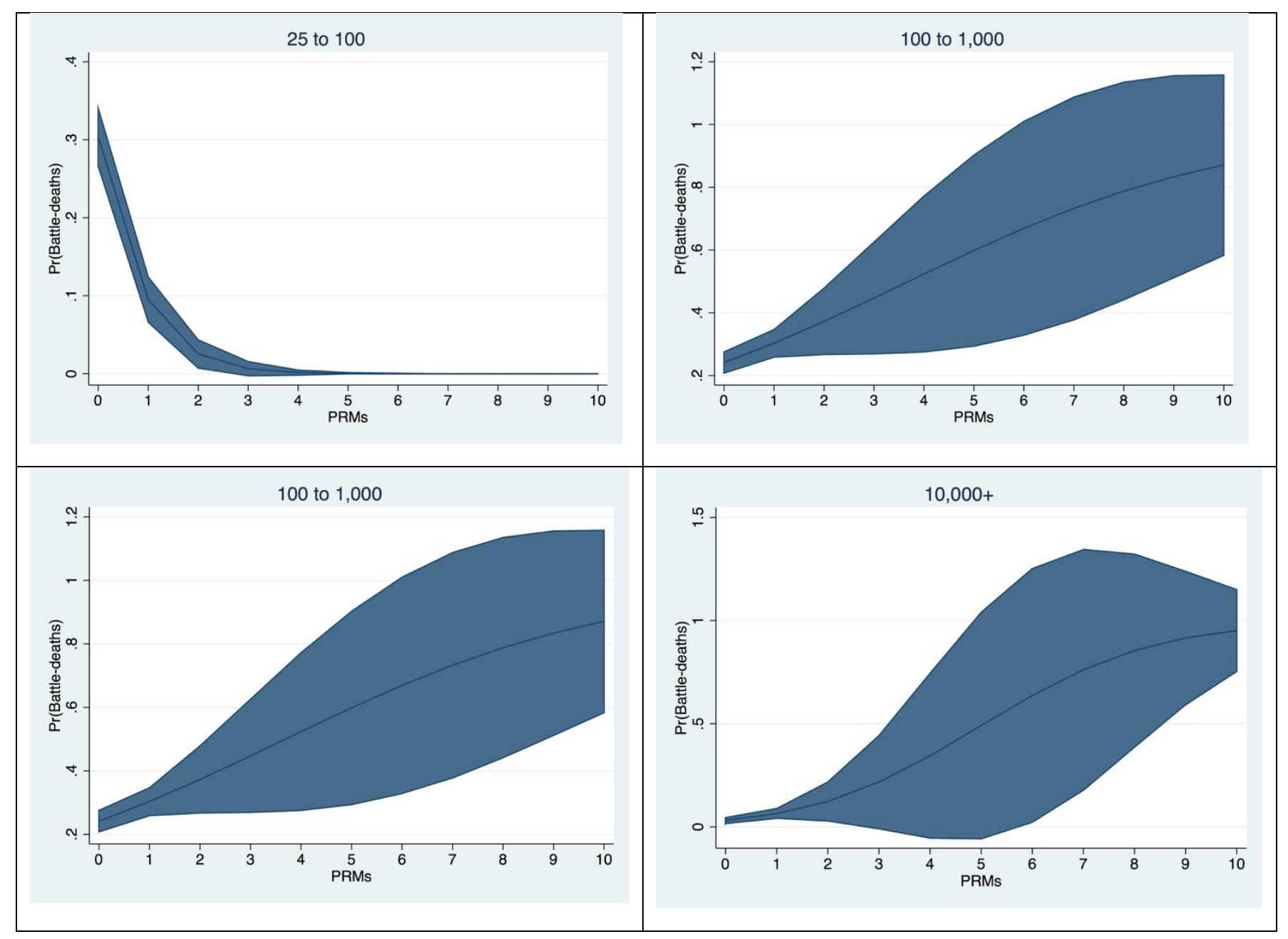

